\title{
Versicherungs-Statistik für 1911
}

über die

\section{unter Reichsaufsicht stehenden Unternehmungen}

\author{
Herausgegeben vom \\ Kaiserlichen Aufsichtsamte für Privatversicherung \\ Mit einer Tafel
}

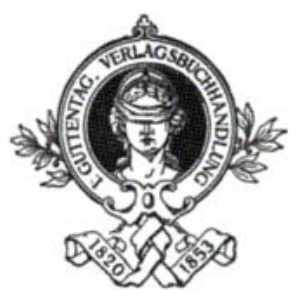

Berlin 1913

J. Guttentag, Verlagsbuchhandlung, G.m.b.H. 
